\title{
Efektivitas Penggunaan Metode Aerasi, Koagulasi Biji Kelor dan Filtrasi dalam Penurunan Nilai Zat Besi (Fe) pada Air Gambut
}

\author{
Dedy Pranataa, Nurhasanaha*, Zulfian ${ }^{\mathrm{b}}$ \\ aProgram Studi Fisika, FMIPA Universitas Tanjungpura, \\ bProgram Studi Geofisika, FMIPA Universitas Tanjungpura \\ *Email : nurhasanah@physics.untan.ac.id
}

\begin{abstract}
Abstrak
Telah dilakukan penelitian yang bertujuan untuk menentukan efektivitas penggunaan metode aerasi, koagulasi biji kelor dan filtrasi dalam penurunan nilai zat besi (Fe) air gambut serta menentukan kualitas air. Sampel air berupa air gambut, diproses dengan menggunakan metode aerasi, koagulasi biji kelor dan filtrasi. Parameter yang diuji meliputi $\mathrm{pH}$ dan zat besi (Fe). Kondisi awal air tanah gambut sebelum menggunakan metode aerasi, koagulasi biji kelor dan filtrasi yaitu nilai pH sebesar 3,5, nilai TDS sebesar $38 \mathrm{mg} / \mathrm{L}$, nilai kekeruhan sebesar 4,13 NTU, dan Fe sebesar 0,91 mg/L. Berdasarkan penggunaan metode koagulasi biji kelor untuk semua konsentrasi diketahui nilai parameter pH sebesar 3,5 s.d. 3,9. Hasil filtrasi memiliki nilai pH sebesar 3,6 s.d. 6,2, sehingga terlihat bahwa parameter pH belum memenuhi standar baku mutu. Parameter Fe telah memenuhi kualitas air bersih pada penggunaan metode koagulasi biji kelor dengan efektivitas mencapai 92\%. Proses tersebut mampu menurunkan Fe dari 0,91 mg/L menjadi 0,077 mg/L. Penggunaan metode filtrasi tertinggi mencapai 93\% berarti mampu menurunkan Fe dari $0,91 \mathrm{mg} / \mathrm{L}$ menjadi $0,063 \mathrm{mg} / \mathrm{L}$ pada konsentrasi $1 / 50$. Penurunan nilai $\mathrm{Fe}$ air gambut efektif dilakukan dengan menggunakan metode aerasi, koagulasi biji kelor dan filtrasi.
\end{abstract}

Kata Kunci: Aerasi, Air Gambut, Filtrasi, Koagulasi Biji Kelor, Zat Besi

\section{Pendahuluan}

Air merupakan kebutuhan yang sangat penting bagi semua manusia di dunia. Air dimanfaatkan untuk keperluan sehari-hari, seperti untuk minum, memasak, mandi dan untuk keperluan lainnya. Menurut Peraturan Menteri Kesehatan Republik Indonesia No.492/MENKES/PER/IV/2010 kualitas air minum yang memenuhi standar persyaratan kesehatan adalah tidak berbau, tidak berwarna dan tidak berasa. Air gambut memiliki ciri-ciri yaitu nilai $\mathrm{pH}$ sekitar 3-4 yang bersifat sangat asam, dengan kadar organik, kadar besi dan kadar mangan yang tinggi serta berwarna kuning atau coklat tua sehingga tidak layak untuk dijadikan air baku dan air minum [1].

Kebutuhan air bersih terus meningkat sejalan dengan pertumbuhan penduduk dan industri. Di kabupaten Kubu Raya, jenis air baku yang digunakan berupa air gambut. Kualitas air belum sesuai standar baku mutu air minum dan kapasitas pengolahannya belum bisa melayani masyarakat secara keseluruhan. Sekitar 13,18\% komplain dan protes masyarakat terhadap air bersih (PDAM Kubu Raya). Untuk menanggulangi masalah tersebut, salah satu alternatif yang dapat dilakukan adalah dengan cara mengolah air tersebut sehingga mempunyai kualitas yang memenuhi syarat kesehatan.

Peningkatan kualitas air tanah gambut telah dilakukan, diantaranya menggunakan elektrokoagulasi dengan hasil mampu mencapai nilai pH optimum 7 dalam waktu kontak 120 menit dan tegangan $30 \mathrm{~V}$ [2]. Menggunakan metode elektrokoagulasi dengan penambahan $\mathrm{NaCl}$ (garam) menghasikan nilai $\mathrm{pH}$ dengan $\mathrm{pH}$ optimum sebesar 7, zat besi (Fe) sebesar $0 \mathrm{mg} / \mathrm{L}$ pada waktu kontak 300 menit [3].

Aerasi merupakan sistem oksigenasi melalui penangkapan $\mathrm{O}_{2}$ dari udara pada air olahan yang akan diproses. Pemasukan $\mathrm{O}_{2}$ bertujuan agar $\mathrm{O}_{2}$ bereaksi dengan kation dalam air olahan. Reaksi tersebut menghasilkan oksidasi logam yang sukar larut dalam air sehingga mengendap [4]. Karena akibat hal tersebut, Martianus, 2017 memperoleh hasil pengukuran dari metode aerasi dengan nilai $\mathrm{pH}$ dan zat besi (Fe) terendah adalah 2,65 dan 12,02 mg/L kemudian tertinggi adalah 3,02 dan 12,87 mg/L [5].

Penambahan zat koagulan bisa berasal dari bahan kimia maupun dari bahan alami. Biji kelor (Moringa Oleifera) merupakan koagulan alami yang mempunyai kemampuan sebagai koagulan dan anti mikroba. Kelebihan biji buah kelor sebagai koagulan alami dibandingkan koagulan kimia seperti tawas adalah kemampuannya untuk mengendapkan berbagai ion logam terlarut dan bakteri-bakteri berbahaya serta mudah diperoleh di lingkungan sekitar [6]. Serbuk biji kelor dapat menurunkan kadar ion $\mathrm{Fe}, \mathrm{Cu}$ dan Mn serta kekeruhan. Menurut Yusrin biji kelor efektif menurunkan kadar besi dalam 
air dengan penambahan 6 biji kelor terhadap larutan uji Fe (II) dengan waktu perendaman 30 menit dengan rata-rata hasil degradasi 43,28\% [7]. Menurut Rusdi biji kelor mampu membuat parameter $\mathrm{pH}$ air waduk krenceng menjadi air bersih dengan kondisi optimum biji kelor yaitu pada konsentrasi $400 \mathrm{ppm}$ dan waktu pengendapan 12 menit dengan penurunan $\mathrm{pH}$ $7,7 \%$ [8].

Filtrasi adalalah proses pemisahan komponen padatan yang terkandung di dalam air dengan melewatkannya melalui media yang berpori atau bahan berpori lainnya. Materialmaterial yang digunakan sebagai filter yaitu karbonaktif, resin, zeolit, batu kerikil, ijuk dan botol bekas. Metode filtrasi untuk peningkatan kualitas $\mathrm{pH}$ dan zat besi (Fe) dari sumur gali diperoleh nilai $\mathrm{pH}$ optimum sebesar 7,73 dan zat besi (Fe) sebesar 0,6 mg/L [9].

Pada penelitian ini dilakukan pengolahan air gambut menjadi air bersih melalui metode aerasi, koagulasi biji kelor dan filtrasi. Parameter yang digunakan adalah $\mathrm{pH}$ dan zat besi (Fe), karena kadar ini cukup tinggi pada air gambut. Diharapkan penelitian ini dapat memberi solusi untuk masalah kualitas air yang kurang baik, membantu penyediaan air bersih yang mudah dan murah.

\section{Metodologi}

Alat-alat yang digunakan pada penelitian ini yaitu, metode aerasi: wadah untuk menampung air tanah gambut, wadah penampungan untuk air sebelum dan sesudah penjernihan, keranjang untuk wadah pada proses aerasinya, tiang penyangga untuk proses aerasi. Metode koagulasi biji kelor: penumbuk untuk menumbuk biji kelor, mangkok kecil untuk menyimpan hasil tumbukan biji kelor, mangkok besar untuk alas menumbuk biji kelor, wadah untuk menyimpan air hasil metode koagulasi biji kelor, kran untuk mengalirkan air hasil metode koagulasi biji kelor. Metode filtrasi: (wadah untuk proses metode filtrasi, kran untuk mengalirkan air hasil metode filtrasi). Peralatan lainnya: spidol, lem tembak takaran, gergaji, solder, TDS (Total Dissolved Solid) meter, $\mathrm{pH}$ meter, turbidimeter, neraca digital dan palu.

Bahan yang digunakan pada penelitian adalah air tanah gambut yang diambil dari parit yang terletak di Jalan Wonodadi 2, Kabupaten Kubu Raya. Batu kecil untuk proses aerasi, biji kelor (Moringa Oleifera) yang dihaluskan untuk proses koagulasi alami, pasir untuk menghilangkan kekeruhan pada air, ijuk untuk menghilangkan kandungan lumpur tanah dalam sampel, arang untuk menghilangkan bau, warna, dan logam berat yang terlarut dalam sampel, batu koral untuk menyerap kandungan lumpur atau penyaringan kotoran halus pada sampel.

2.1. Langkah Kerja

1) Rancang bangun sistem penelitian

Metode yang digunakan dalam proses penjernihan air gambut yaitu metode aerasi, koagulasi biji kelor dan filtrasi. Proses pertama terdiri dari 1 wadah untuk menampung air tanah gambut yang akan dijernihkan, 1 keranjang untuk proses metode aerasi, 1 wadah untuk proses koagulasi biji kelor, 1 wadah untuk proses filtrasi dan 1 wadah untuk menampung air hasil metode aerasi. Rancang Bangun Sistem penjernihan air dapat dilihat pada Gambar 1 .

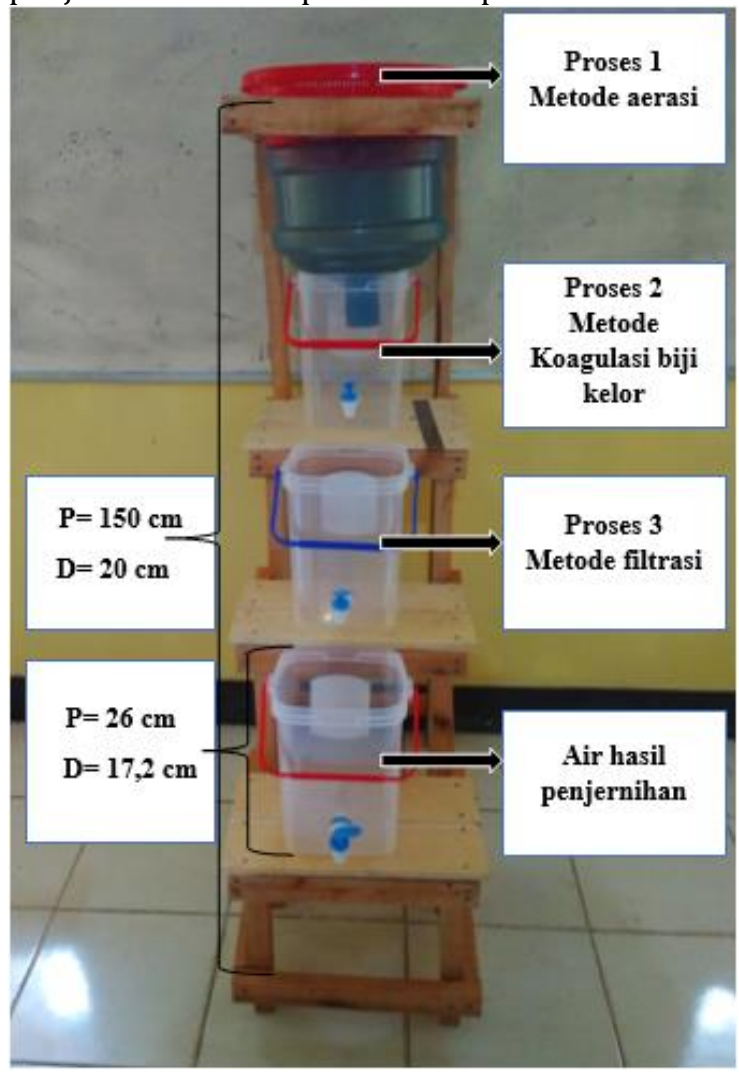

Gambar 1. Alat Penelitian

a) Metode aerasi

Langkah-langkah untuk membuat alat metode aerasi adalah mengeringkan dan menempatkannya dalam keranjang. Menuangkan air melalui kerikil dari ketinggian $100 \mathrm{~cm}$. Sehingga butiran air terkontak dengan udara.

b) Metode koagulasi biji kelor

Proses koagulasi biji kelor berfungsi untuk mengubah warna air gambut yang semula berwarna kuning atau cokelat tua (pekat) menjadi bening. Biji kelor yang telah dibersihkan ditumbuk hingga halus. Biji kelor tersebut dimasukan dalam air gambut dengan variasi konsentrasi seperti pada Tabel 1 dan didiamkan selama 1 - 3 jam. 
Tabel 1. Variasi nilai perbandingan sampel serbuk biji kelor dengan volume air gambut (konsentrasi)

\begin{tabular}{cc}
\hline No & Konsentrasi (gram/mL) \\
\hline 1 & $1 / 25$ \\
2 & $1 / 50$ \\
3 & $1 / 75$ \\
4 & $1 / 100$ \\
5 & $1 / 150$ \\
\hline
\end{tabular}

c) Metode filtrasi

Air hasil metode koagulasi dimasukan dalam wadah filtrasi, lalu air tersebut akan diproses untuk metode filtrasi. Metode filtrasi berfungsi untuk menyaring atau memisahkan padatan yang terkandung dalam air dan mengurangi kekeruhan air tanah gambut. Wadah filrasi terdiri dari beberapa lapisan material seperti pasir, ijuk, arang dan batu koral.

Langkah pertama untuk metode filtrasi adalah siapkan bahan seperti pasir, ijuk, arang dan batu koral. Kemudian bahan tersebut dimasukan dalam wadah untuk metode filtrasi, dengan susunan dari atas sampai bawah yaitu pasir $(3 \mathrm{~cm})$, ijuk $(4 \mathrm{~cm})$, arang $(4 \mathrm{~cm})$, ijuk $(4 \mathrm{~cm})$, arang $(4 \mathrm{~cm})$ dan batu koral $(4 \mathrm{~cm})$. Air hasil metode koagulasi dimasukan kedalam metode filtrasi. Pindahkan air tanah gambut hasil metode filtrasi dalam wadah baru.

\subsection{Pengujian sampel}

Pengujian sampel meliputi uji sampel sebelum pengolahan, uji sebelum proses areasi, uji sebelum proses koaguluasi biji kelor, uji sebelum proses filtrasi dan sesudah pengolahan.

Parameter pengujian sampel adalah derajat keasaman $(\mathrm{pH})$ menggunakan $\mathrm{pH}$ meter, Total Dissolved Solids dengan TDS meter untuk mengetahui banyaknya zat terlarut yang terkandung dalam air gambut. Kekeruhan sampel diuji menggunakan turbidimeter untuk mengetahui nilai kekeruhan dan kandungan zat besi (Fe) diuji menggunakan Spektrometri Serapan Atom (AAS)

\subsection{Analisis}

Untuk mengetahui peningkatan kualitas air gambut dan efektivitas metode aerasi, koagulasi biji kelor, dan filtrasi dilakukan melalui analisis kualitatif. Nilai yang diperoleh dibandingkan dengan nilai standar baku mutu kualitas air bersih yang telah ditetapkan oleh Peraturan Menteri Kesehatan Republik Indnesia No. 429/MENKES/PER/IV/2010 tentang persyaratan kualitas air minum [1].

\section{Hasil dan Pembahasan}

3.1. Sampel air gambut

Air gambut yang digunakan memiliki karakteristik air gambut seperti ditunjukkan pada Tabel 2 berikut:

Tabel 2. Hasil uji karakteristik air gambut

\begin{tabular}{ccccc}
\hline No & Parameter & Nilai & $\begin{array}{c}\text { Standar } \\
\text { Baku }\end{array}$ & Kualitas \\
\hline 1 & $\mathrm{pH}$ & 3,5 & $\begin{array}{c}6,5- \\
8,5\end{array}$ & $\begin{array}{c}\text { Tidak } \\
\text { Layak }\end{array}$ \\
\hline 2 & TDS & $\begin{array}{c}38 \\
\mathrm{mg} / \mathrm{L}\end{array}$ & $\begin{array}{c}500 \\
\mathrm{mg} / \mathrm{L}\end{array}$ & Layak \\
\hline 3 & Kekeruhan & $\begin{array}{c}4,13 \\
\mathrm{NTU}\end{array}$ & $5 \mathrm{NTU}$ & Layak \\
\hline 4 & $\begin{array}{c}\text { Zat Besi } \\
(\mathrm{Fe})\end{array}$ & $\begin{array}{c}0,91 \\
\mathrm{mg} / \mathrm{L}\end{array}$ & $\begin{array}{c}0,3 \\
\mathrm{mg} / \mathrm{L}\end{array}$ & $\begin{array}{c}\text { Tidak } \\
\text { Layak }\end{array}$ \\
\hline
\end{tabular}

Tabel 2 menunjukkan hasil uji karakteristik air gambut dengan nilai $\mathrm{pH}$ rendah dan zat besi (Fe) tinggi. Kondisi air tersebut tidak memenuhi standar baku mutu yang telah ditetapkan Peraturan Menteri Kesehatan Republik Indonesia Nomor. 429/Menkes/Per/IV/2010. Sedangkan pada parameter TDS dan kekeruhan telah memenuhi standar baku mutu kualitas air bersih, namun masih terlarut sedikit zat organik.

3.2. Hasil metode aerasi, koagulasi biji kelor dan filtrasi.

a. Metode aerasi

Setelah dilakukan analisis berdasarkan parameter $\mathrm{pH}$ dan zat besi (Fe), pada metode aerasi diperoleh karakteristik seperti pada tabel 3.

Tabel 3. Hasil uji karakteristik air gambut setelah melewati proses metode aerasi.

\begin{tabular}{ccccc}
\hline No & Parameter & Nilai & $\begin{array}{c}\text { Standar } \\
\text { Baku }\end{array}$ & Kualitas \\
\hline \multirow{2}{*}{1} & $\mathrm{pH}$ & 3,7 & $\begin{array}{c}6,5- \\
8,5\end{array}$ & Tidak \\
& & & Layak \\
2 & Zat Besi & 0,937 & 0,3 & Tidak \\
& $(\mathrm{Fe})$ & $\mathrm{mg} / \mathrm{L}$ & $\mathrm{mg} / \mathrm{L}$ & Layak \\
\hline
\end{tabular}

Tabel 3 memperlihatkan kondisi air gambut pada parameter $\mathrm{pH}$ setelah melalui metode aerasi didapatkan nilai sebesar 3,7. Hal tersebut menunjukkan bahwa air gambut masih bersifat asam (nilai $\mathrm{pH}<7$ ). Pada parameter zat besi (Fe) terlarut diperoleh nilai sebesar 0,937 mg/L, menunjukkan kandungan zat besi (Fe) pada air gambut meningkat karena reaksi air mengandung zat besi $(\mathrm{Fe})$ bereaksi dengan $\mathrm{O}_{2}$ dari udara menghasilkan oksidasi logam yang sukar terlarut dalam air. Ion besi terlarut dapat 
mengakibatkan warna kecoklatan, rasa, dan bau pada air. Air gambut dengan parameter $\mathrm{pH}$ dan zat besi (Fe) belum memenuhi standar baku mutu kualitas air bersih sesuai dengan persyaratan kualitas air minum yang tertera pada Peraturan Menteri Kesehatan Republik Indonesia Nomor. 429/Menkes/Per/IV/2010.

b. Metode koagulasi biji kelor

Pada metode ini dilakukan variasi antara jumlah air gambut dengan serbuk biji kelor dan selanjutnya dilakukan analisis berdasarkan parameter $\mathrm{pH}$ dan zat besi (Fe). Hasilnya dapat dilihat pada Tabel 4 .

Tabel 4. Hasil uji karakteristik air gambut setelah melewati proses metode koagulasi biji kelor.

\begin{tabular}{cccc}
\hline No & $\begin{array}{c}\text { Konsentrasi } \\
\text { (gram/ml) }\end{array}$ & $\mathrm{pH}$ & $\begin{array}{c}\text { Parameter } \\
\text { Zat Besi (Fe) } \\
(\mathrm{mg} / \mathrm{L})\end{array}$ \\
\hline 1 & $1 / 25$ & 3,5 & 0,077 \\
2 & $1 / 50$ & 3,9 & 0,177 \\
3 & $1 / 75$ & 3,5 & 0,167 \\
4 & $1 / 100$ & 3,9 & 0,222 \\
5 & $1 / 150$ & 3,7 & 0,109 \\
\hline
\end{tabular}

Tabel 4 menunjukkan hasil pengolahan air melalui metode koagulasi biji kelor. Proses ini menaikkan pH hingga 3,9 dan menurunkan zat besi (Fe) hingga 0,077 mg/L. Hal tersebut terjadi karena proses koagulasi dapat menghilangkan sebagian atau seluruh zat terlarut. Zat-zat kimia yang ditambahkan kedalam sistem suspensi untuk menghasilkan pengendapan.

Dari Tabel 4 juga menunjukkan pengaruh konsentrasi koagulan terhadap $\mathrm{pH}$ tidak signifikan tetapi terhadap kadar besi cenderung naik. Hal tersebut terjadi karena biji kelor mengandung senyawa bioaktif rhammnosyloxybenzil-isothiocyanate, yang mampu mengadopsi dan menetralisir partikel-partikel lumpur serta logam yang terkandung dalam limbah suspensi dengan partikel kotoran melayang dalam air. Pada metode koagulasi biji kelor diperoleh efektivitas tertinggi $92 \%$ dan terendah $76 \%$.

\section{c. Metode filtrasi}

Setelah dilakukan analisis berdasarkan parameter $\mathrm{pH}$ dan zat besi (Fe), pada hasil metode filtrasi diperoleh karakteristik seperti pada Tabel 5.
Tabel 5. Hasil uji karakteristik air gambut setelah melewati proses metode filtrasi

\begin{tabular}{cccc}
\hline No & $\begin{array}{c}\text { Konsentrasi } \\
\text { (gram/ml) }\end{array}$ & pH & $\begin{array}{c}\text { Parameter } \\
\text { Zat Besi (Fe) } \\
\text { (mg/L) }\end{array}$ \\
\hline 1 & $1 / 25$ & 3,6 & 0,113 \\
2 & $1 / 50$ & 6,2 & 0,063 \\
3 & $1 / 75$ & 4,4 & 0,09 \\
4 & $1 / 100$ & 4,5 & 0,168 \\
5 & $1 / 150$ & 4,5 & 0,072 \\
\hline
\end{tabular}

Tabel 5 menunjukkan hasil pengolahan air melalui metode filtrasi, $\mathrm{pH}$ air gambut tertinggi diperoleh 6,2. Terdapat perubahan yang cukup besar yang mampu menaikan $\mathrm{pH}$ sebesar 2,3. Hal ini dikarenakan ion hidrogen sendiri diadsorpsi dengan kuat, sebagian karena $\mathrm{pH}$ mempengaruhi adsoprsi dari beberapa senyawa. Asam argonik lebih mudah diadsorpsi pada $\mathrm{pH}$ rendah, sedangkan adsorpsi basa organik terjadi dengan mudah pada $\mathrm{pH}$ tinggi.

Sedangkan berdasarkan parameter zat besi (Fe) diperoleh kadar tertinggi 0,168 mg/L dan kadar terendah 0,063 mg/L. Hal ini memperlihatkan proses filtrasi mampu menurunkan zat besi (Fe) hingga $0,1 \mathrm{mg} / \mathrm{L}$. Hal ini disebabkan senyawa amorf yang dihasilkan dari bahan-bahan yang mengandung karbon atau arang yang diperlakukan secara khusus untuk mendapatkan daya serap (adsorpsi) yang tinggi. Pada proses tersebut terjadi penghilangan hidrogen, gas-gas dan air dari permukaan karbon sehingga terjadi perubahan fisik pada permukaannya. Sehingga diperoleh efektivitas metode filtrasi tertinggi 93\% dan terendah $82 \%$.

\subsection{Analisis parameter air gambut}

a. Parameter $\mathrm{pH}$

Nilai pH menunjukkan derajat keasaman air dimana berupa derajat asam, netral dan basa. Perubaan nilai $\mathrm{pH}$ terjadi setelah melalui proses metode aerasi, metode koagulasi biji kelor dan filtrasi. Perubahan tersebut dapat dilihat pada gambar 2. Gambar tersebut menunjukkan tiap proses menyebabkan peningkatan $\mathrm{pH}$. $\mathrm{PH}$ awal 3,5 , setelah melewati masing-masing proses terlihat bahwa pH rata-rata menjadi 3,7 dan 4,62. Perubahan paling besar terjadi pada konsentrasi $1 / 50$. 
Peningkatan tinggi atau rendahnya nilai $\mathrm{pH}$ air tergantung pada beberapa faktor yaitu: konsentrasi gas-gas dalam air seperti $\mathrm{CO}_{2}$, konsentrasi garam-garam karbonat dan bikarbonat dan proses dekomposisi bahan organik. Meskipun nilai $\mathrm{pH}$ belum memenuhi standar baku mutu.

b. Parameter zat besi (Fe)

Kadar besi dari sampel air gambut setelah melalui proses metode koagulasi biji kelor menjadi salah satu faktor yang dapat mempengaruhi kualitas sampel air gambut tersebut. Kadar besi pada air disebabkan tingginya ion besi terlarut. Perubaan nilai zat besi (Fe) terjadi setelah melalui proses metode aerasi, metode koagulasi biji kelor dan filtrasi.
Perubahan tersebut dapat dilihat pada Gambar 3. Gambar tersebut menunjukkan tiap proses menyebabkan peningkatan zat besi (Fe). Zat besi (Fe) awal 0,077, setelah melewati masingmasing proses terlihat bahwa rata-rata menjadi 0,15 dan 0,1 . Perubahan paling besar terjadi pada konsentrasi 1/50. Peningkatan dan penurunan nilai zat besi (Fe) dipengaruhi oleh proses pemisahan komponen padatan yang terkandung di dalam air dengan melewatkannya melalui media yang berpori atau bahan berpori lainnya untuk memisahkan padatan dalam air tersebut baik yang berupa suspensi maupun koloid. Selain itu, dapat mengurangi kandungan bakteri, bau, rasa, kandungan logam berat lainnya. Nilai zat besi (Fe) sudah memenuhi standar baku mutu.

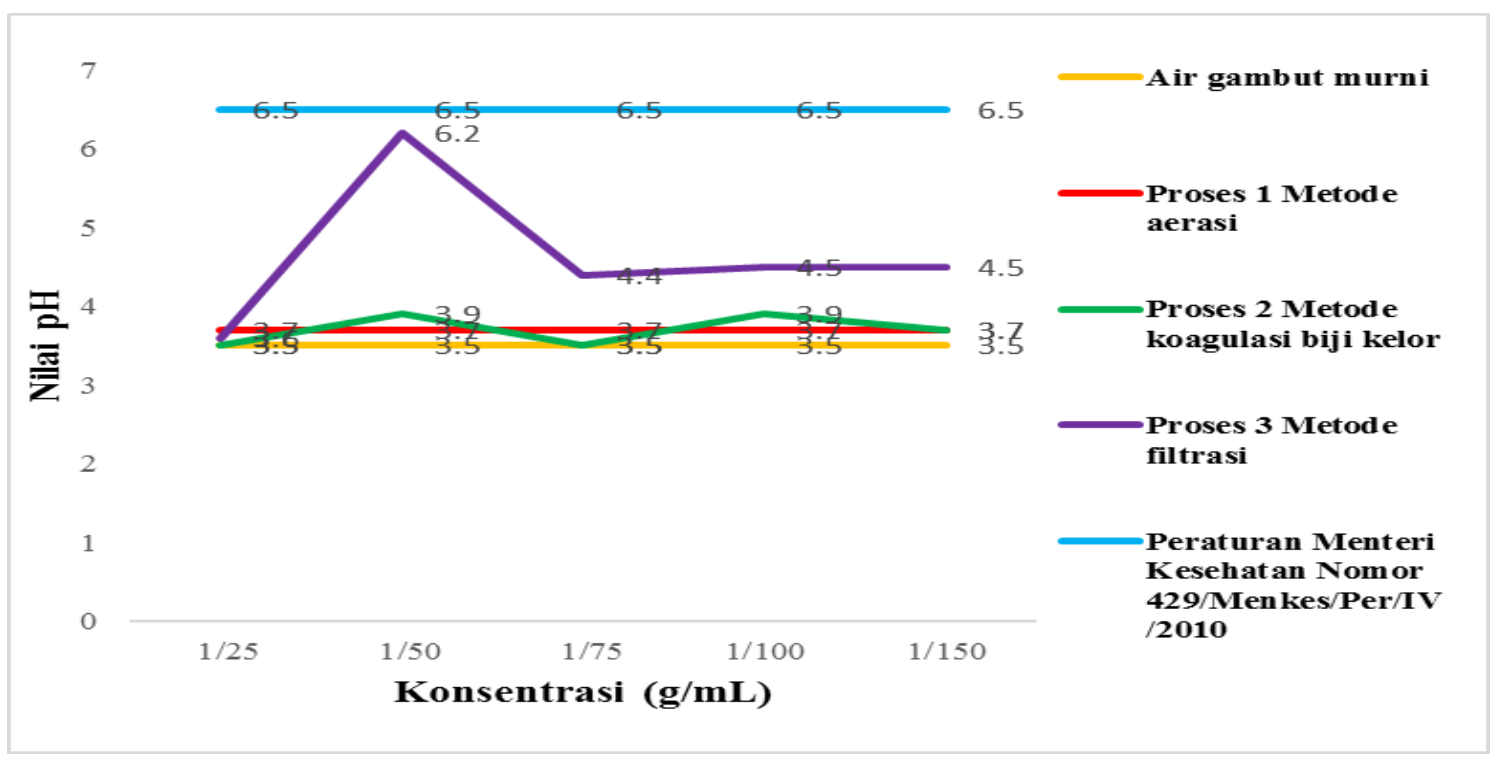

Gambar 2. Grafik hasil nilai pH untuk metode aerasi, koagulasi biji kelor dan metode filtrasi

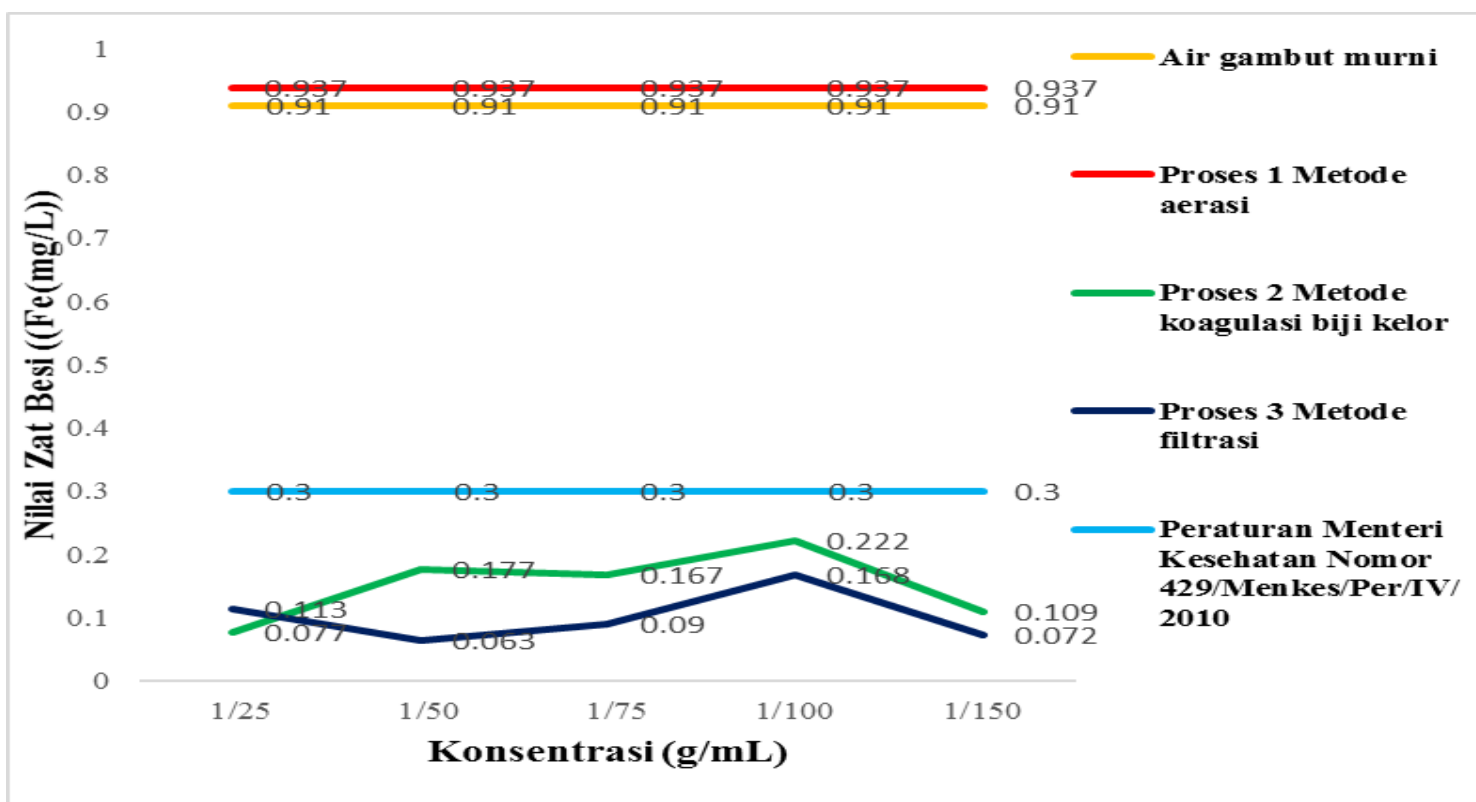

Gambar 3. Grafik hasil nilai zat besi (Fe) untuk metode aerasi, koagulasi biji kelor dan metode filtrasi 


\section{Kesimpulan}

Proses pengolahan air menggunakan metode aerasi, koagulasi biji kelor dan filtrasi yang telah dilakukan pada air gambut. Pada parameter $\mathrm{pH}$ air gambut tersebut belum layak untuk dijadikan air bersih. Untuk parameter zat besi (Fe) air gambut sudah layak untuk digunakan karena kadar zat besi (Fe) kurang dari $0,3 \mathrm{mg} / \mathrm{L}$.

\section{DaftarPustaka}

[1] Peraturan Menteri Kesehatan Republik Indonesia No.492/MENKES/PER/IV/ 2010 Tentang Persyaratan Kualitas Air Minum, 2010.

[2] Rasidah.; Lapanporo B. P.; dan Nurhasanah., 2017, Peningkatan Kualitas Air Tanah Gambut dengan Menggunakan Metode Elektrokoagulasi, Jurnal PRISMA Fisika 5(2), 77-82.

[3] Lavianiga, F. E.; Nurhasanah.; dan Lapanporo, B. P., 2019, Peningkatan Kualitas Air Gambut Menggunakan Metode Elektrokoagulasi dengan Penambahan Garam, Jurnal PRISMA FISIKA, Vol. 7, No. 1, Hal. $34-39$.

[4] Yuniar, A, A., 2014, Rancang Bangun Unit Pengolahan Air Gambut dengan Menggunakan Proses Aerasi, Koagulasi, dan Filtrasi untuk Menurunkan Kandungan Warna dan Besi (Fe), Politeknik Negeri Sriwijaya.

[5] Manurung, M.; Ivansyah, 0.; dan Nurhasanah., 2017, Analisis Kualitas Air Sumur Bor di Pontianak Setelah Proses Penjernihan dengan Metode Aerasi, Sedimentasi dan Filtrasi, PRISMA FISIKA, Vol. V, No. 1, Hal. 45-50.

[6] Suriawiria, U., Aneka Manfaat Kelor, 2003, http://www.kompas.com

[7] Yusrin.; Mukaromah, A. H.; dan Wahyuni, E. T., 2015, Penurunan Kadar Fe dalam Air dengan Biji Kelor (Moringa Oleifera), The 2nd University Research Coloquium.

[8] Rusdi, T. B.; Sidi, P.; dan Pratama. R., 2014, Pengaruh Konsentrasi dan Waktu Pengendapan Biji Kelor terhadap pH, Kekeruhan dan Warna Air Waduk Krenceng, Jurnal Integrasi Proses Vol. 5, No. 1, 46 - 50.

[9] Mushadi. A.; Surendro. B.; Rakhmawati, A.; dan Amin, M., 2018, Peningkatan Kualitas $\mathrm{pH}, \mathrm{Fe}$ dan Kekeruhan dari Air Sumur Gali dengan Metode Filtrasi, Jurnal Riset Rekayasa Sipil Universitas Sebelas Maret, 105-113. 